This PDF is a selection from a published volume from the National Bureau of Economic Research

Volume Title: The Rate and Direction of Inventive Activity Revisited

Volume Author/Editor: Josh Lerner and Scott Stern, editors

Volume Publisher: University of Chicago Press

Volume ISBN: 0-226-47303-1; 978-0-226-47303-1 (cloth)

Volume URL: http://www.nber.org/books/lern11-1

Conference Date: September 30 - October 2, 2010

Publication Date: March 2012

Chapter Title: Putting Economic Ideas Back into Innovation Policy

Chapter Authors: R. Glenn Hubbard

Chapter URL: http://www.nber.org/chapters/c12377

Chapter pages in book: (p. 669 - 672) 


\title{
Putting Economic Ideas Back into Innovation Policy
}

\author{
R. Glenn Hubbard
}

When Josh Lerner asked me to offer panel remarks, he wanted me to discuss both the art and science of innovation policy. That is an enormous subject, and Bronwyn Hall made it even larger by now encompassing social factors in her introduction. As an economist, I'll stick to my own narrower knitting.

Some of the themes from earlier in the conference about basic science and engineering, importantly about diffusion through both professional talent and entrepreneurs, set up very nicely what I want to talk about. As an economist who has also been in a policy chair and who is a business school dean, when I speak to businesspeople who want to discuss innovation, they are generally people who benefited from the serendipity of a good draw, or they would not be seeing me-I rarely see the bad draws in my job. And policymakers, I think, face the same issue.

When I hear the phrase "innovation policy," based on my time in Washington, where I heard it on more than a few occasions, my antennae go up. That is because sometimes this discussion is as much about entrepreneurship, a related but not entirely coincident subject or, worse in my experience, it is actually about rent seeking. The role of policy, when thinking about innovation, is less about innovation's per se features, which interest us as economists, but more about links to economic growth and productivity growth. And policy discussions, in this regard, I think are often very specific. I will give some examples in a moment of how that might be unfortunate.

Despite the admonition from our profession that we should more narrowly focus on what I think of as conditions supporting innovation and

R. Glenn Hubbard is dean as well as the Russell L. Carson Professor of Finance and Economics at Columbia Business School, professor of economics at Columbia University, and a research associate of the National Bureau of Economic Research. 
technical change - or, as I will try to argue, on the diffusion of innovationI think there is also value in thinking about it first in a very big picture way, like in Joel Mokyr's work over many years. I am also thinking of the more pointed discussion of the organization of innovative cultures that you will find in my colleague Ned Phelps' Nobel lecture.

I think the good news for us as economists is that both the economics of innovation and the economics of innovation policy do have sound empirical bases for discussion. But I think we need to apply the arguments in the right setting, and we need to focus, with growth in mind, on diffusion.

So let me start first by asking what we mean by "innovation," because policymakers often use this word in very different ways. What you might mean are individual acts of innovation. I think of solo inventions, like Willis Carrier with air conditioning, like entrepreneurship. I think that is what many policymakers mean when they start to ask questions. Or we might mean something more like a process of innovation or a climate for innovation in which continuous change is made. From a policy perspective, we need to be interested in both, but policies that promote individual entrepreneurship or risk taking are not necessarily the same as those that enhance the climate for innovation. And we should be interested as much in the diffusion of innovation as the overarching policy concern should be with growth and not about innovation per se.

But the second thing to ask is what we mean by policy. When I was Chairman of the Council of Economic Advisers, John Doerr, as an eminent venture capitalist, came with many business leaders in tow to meet with me. The business leaders gave a long presentation about the tech bubble and the meltdown, after which John turned to me and asked, "So what are your ideas to do about it?" I looked at them, and I said, "Gee, I thought it was the other way around: I thought that was what I was asking you!" Part of the policy discussion, then, often calls for individual policy responses to particular issues or situations. I think that is unwise.

A second type of concern comes up when policymakers talk to the business community. Generally, there the emphasis is often on very macro concerns. I was joking with Bronwyn that whenever I have the privilege to visit my friends at the Hoover Institution, I invariably hear that if only we could reduce the capital gains tax another percentage point, a torrent of innovation would hit the country. And I am quite sympathetic as an individual to such tax arguments, but I am skeptical from an overall policy perspective.

There are other things that we could do: I think here of the work the World Bank does in looking closely at business indicators, their approach being what I think of as more a kind of "league table" for thinking about zthe overall climate for innovation. This approach is probably less relevant for the United States, where conditions are much better, but definitely relevant in thinking about policies abroad. In that regard, I think we have to be careful about slipping from a discussion of innovation policy, a hard enough 
term to define, into the word "competitiveness," which makes me very nervous. Such a term is easy for us to think about for a firm: survive for a long time, you are competitive. If you lose money and go out of business, you are not competitive. But it is a much harder thing to think about as a public policy for a country.

So how, then, should we think about the scope of innovation, and then policy? There are three things one needs to think about in innovation policy. The first is obvious to policymakers. The others, I think, may be as important, if not more important.

The factor that grips policymakers is to think about the product market, first the development of new products or technological change. It is in the product market where we often see, too, somewhat unfortunate interventions to which I come to in a moment. What I think are probably as important, if not more important, are what I would call enablers. By this I mean policies about the labor market (which might, for example, be policies that encourage mobility) and, particularly, management practices and productivity growth. I also think of financial markets in this regard, not financial innovation on its own but markets for risk capital and risk taking. From a policy perspective, in this regard, thinking about innovation and productivity growth is not just about technical change. It really takes a village.

Second, in terms of the scope of policy, there are three considerations. One often discussed factor is the encouragement of $R \& D$. Tax policy is usually the lever discussed in Washington, and it has a moderate effect. A bigger deal is, of course, the intellectual property regime and things that we learn from individual regulatory environments, like the energy environment or health care. A second policy discussion returns to innovation, and therein lies a number of significant policy concerns, ranging from tax policy to patent regimes to antitrust policy. And, third, on disseminating innovation, the policy environment toward management and labor practices is very important. Here, I am thinking about the work of Nick Bloom and John Van Reenen and others who study the substantial cross-country and withincountry differences in productivity growth that I think of as at least largely related to the speed of diffusion of innovation led by management practices.

In terms of policy, there have been some successes in promoting innovation in the United States. Some of those successes relate to deregulationin telecommunications, for example. However, some waves of innovation actually come from regulation. The financial services sector comes to mind, where many waves of innovation were stimulated by regulation. And then I think of the policy we have had toward intellectual property - the BayhDole Act and Defense-University collaborations come to mind. The biggest failures come from the problems of being specific in interventions; here, I would think of industrial policy failures, like the Synthetic Fuels Corporation or today, General Motors. 
Now recalling Edison's mix between inspiration and perspiration, policy, like many teachers of entrepreneurship, tends to be so focused on the former and not the latter, and it might be the latter that's more important. And by that I mean not just science, but also about business and management and the policy environment. That is also a more straightforward, if more humble, role for policy. I think of Bob Solow's famous line, "I know there are a lot of industries where there's $\$ 4$ worth of social output for every dollar worth of private output, I just don't know which ones they are." Rarely do policymakers have that kind of humility.

Third, I wanted to close by discussing an important and underemphasized element, which is the policy process. This is something that as economists we do not often think about but that turns out to be critical in talking about the policy of innovation. Normally, at least in a US setting, there are interagency processes for anything involving economic matters. But voices for innovation in Washington typically are often limited to people who write Greek letters on their blackboard. To narrow down who that might be in Washington, one might be the Council of Economic Advisers - at least one hopes. Another might be the science advisors. Interagency processes approaches have tended to be much more successful in things related to finance than to technology, and one might look to success stories of longer-term interagency working groups. I am thinking about just such an experience in the George W. Bush administration, a long-term working group on antitrust and innovation on environmental policy and how to promote low-cost innovation for Homeland Security.

But I will close where Bronwyn Hall led off. Policy is equally likely to involve art as science. 